\title{
THE SOPHISTRY THAT MADE URBAN RENEWAL POSSIBLE
}

\author{
MARTIN ANDERSON*
}

This member of government was at first considered as the most harmless and helpless of all its organs. But it has proved that the power of declaring what the law is, ad libitum, by sapping and mining, slyly, and without alarm, the foundations of the Constitution, can do what open force would not dare to attempt.

\section{-Thomas Jefferson: Letter to Edward Livingston, I825}

For over fifteen years government agencies throughout the United States have been taking private property by eminent domain for the private use of some person other than the original owner. Why? To carry out the federal urban renewal program (FURP). How? Because such action was apparently deemed constitutional by the Supreme Court in $1954^{1}$

The purpose of this article is twofold: first, to summarize briefly the record of the FURP, and second, to analyze the opinion of the Supreme Court on the 1954 Berman v. Parker case, which made urban renewal possible.

Passed in 1949 by Congress, the essential purpose and clear intent of the FURP was to "help" our economic system of free enterprise achieve better housing conditions for all Americans. The decision made by the Supreme Court in 1954 appeared to sanction the constitutionality of the program. Since then the FURP has grown rapidly and it has been endorsed enthusiastically by many well-known, influential people.

Today the consensus seems to be that (I) the program is absolutely necessary, and, except for a few setbacks here and there, is making significant progress, and (2) in spite of some uneasiness over the idea of taking private property by eminent domain for private use, it "must" be all right because the Supreme Court has indicated that it is constitutional.

I disagree. In my judgment the FURP is not necessary, it is not working, and it is clearly unconstitutional.

\section{The Record of the Federal Urban Renewal Program}

The FURP has been a failure. Contrary to the widely publicized claims of the proponents of federally aided and directed urban renewal, the program has worsened the housing situation that it set out to help; it has not revitalized a single city; and

- A.B. I957, summa cum laude, Dartmouth College; M.S. in Engineering and Business Administration, 1958, Thayer School of Engineering and the Tuck School of Business Administration; Ph.D. in Industrial Management, 1962, Massachusetts Institute of Technology. Research Fellow, Joint Center for Urban Studies, Massachusetts Institute of Technology and Harvard University, I96I-I962. Assistant Professor of Finance, Columbia University Graduate School of Business. Author, The Federal Bulidozer: A. Critical ANalysis of Urban Renewal, r949-1962 (I964).

${ }^{2}$ Berman v. Parker, 348 U.S. 26 (1954). 
its costs-both in dollars and personal liberty-have been great. ${ }^{2}$ Seldom have so many people been hurt and so much money been spent with such perverse consequences. Some of the more serious consequences are these:

- From 1950 through 1960, about 126,000 housing units were destroyed in urban renewal areas. Of these, ror,000 were classified as substandard by local renewal officials; 25,000 were sound homes in good condition-some of them in excellent condition. Only about 28,000 housing units were built; 25,000 of them are privately owned, the rest are public housing units. Thus about four times as many homes were destroyed as were built. Those destroyed were predominantly low-rent homes, those built were predominantly high-rent homes.

- As of March 31, 1963, about 609,000 people had been evicted from their homes. I estimate that one million will have been evicted by the end of 1965 . And, according to the Commissioner of Urban Renewal Administration, around four million will be displaced by I972-or one out of every fifty persons living in the United States.

- The FURP has strong racial overtones and is sometimes referred to as the "Negro Removal Program." About two-thirds of those forced to move are Negroes and Puerto Ricans.

- The process is taking a very long time. An average-size urban renewal project can easily run ten to twelve years from the start of planning to the completion of the new construction.

- FURP is very expensive. Many billions have already been spent, and the plans call for vastly increased spending.

- On an overall basis there are strong indications that the program is causing a net decrease in cities' tax revenues.

But in spite of the failures of urban renewal and its negative effects, housing quality in the United States has increased enormously. The economic system of free enterprise has moved powerfully and swiftly toward achieving better housing conditions for all Americans. From $195^{\circ}$ to 1960 , over 18 million standard homes were added to the housing supply. The total number of standard homes increased from 29.I million to 47.7 million, an overall increase of sixty-four per cent. ${ }^{3}$

And these gains were possible to all Americans. For example, the nonwhite population of the United States enjoyed a substantial increase in the quality of its housing. From $195^{\circ}$ to 1960 there was an increase of $1,813,000$ standard units occupied by nonwhites, accompanied by a decrease of 537,000 substandard units. ${ }^{4}$

\footnotetext{
${ }^{2}$ Martin Anderson, The Federal Bulidozer (1964).

'U.S. Dep't of Comamerce, Census of Housing: Ig6o, Final Report HC (I)-I, United States Summary Table O, p. xxxvi.

- Housing and Home Finsnce Agency, Office of the Administrator, Our Nonwhite Population and Its Housing: The Changes Between 1950 and 1960 (May I963).
} 
Virtually all of this was accomplished by private construction, rehabilitation, and demolition efforts financed by massive amounts of private funds. These activities were in no way connected with the FURP.

Thus, facts tell us that the economic system of free enterprise has made enormous gains, while FURP-which was supposed to aid and complement private meanshas actually made the housing situation worse, particularly for low-income families and individuals, and has done so at a high cost. The FURP is acting as a brake on the economic system of free enterprise.

\section{Is THE FURP Constirutional?}

The rest of this article deals basically with one simple, clear issue-the issue of whether or not any government agency in the United States should have the right to take private property by eminent domain for private use.

The basic idea of forcibly seizing the private property of one man, compensating him for it at the appraised value, and then conveying this property to someone else is, I am convinced, considered illegal and immoral by the great majority of the people in the United States-particularly when this abstract principle becomes concrete and people are faced with the prospect of having their own homes seized.

In 1954 the constitutionality of the FURP was challenged. At this time the nine men who were then the Justices of the Supreme Court had the opportunity to stop this program in its infancy before it had a chance to grow into the firmly entrenched giant that it is today, reaching into over $75^{\circ}$ cities and embracing over 1500 projects.

But they did not; instead they released the FURP to interfere with the property rights and lives of millions of city dwellers in the United States. The opinion was written by Justice Douglas and concurred in by the rest of the Court. Since then, the composition of the Court has changed significantly-only four of the Justices remain who participated in this decision. They include Justice Douglas, the author, Chief Justice Warren, and Justices Black and Clark. The five present Justices who did not participate in Berman v. Parker are Harlan, Brennan, Stewart, White, and Goldberg.

It is my contention that the opinion handed down in 1954 is illogical and contains sophistic reasoning. On a quick, superficial reading it may appear plausible, but a careful, detailed reading will reveal basic errors. Following is the complete text of the opinion handed down by the Court in 1954 in the case of Berman v. Parker. ${ }^{5}$ Interspersed through it are my comments on what I consider to be the crucial elements of the opinion.

This is an appeal (28 U.S.C. \$ 1253 ) from the judgment of a three-judge District Court which dismissed a complaint seeking to enjoin the condemnation of appellants' property under the District of Columbia Redevelopment Act of 1945,60 Stat. 790, D.C. Code r95I,

${ }^{8}$ Supra note I. 
$\$$ 5-70I-5-7xg. The challenge was to the constitutionality of the Act, particularly as applied to the taking of appellants' property. The District Court sustained the constitutionality of the Act. II7 F. Supp. 705.

Here the Court clearly identifies the main issue to be decided upon- "the constitutionality of the Act, particularly as applied to the taking of the appellants' property."

By $\S 2$ of the Act, Congress made a "legislative determination" that "owing to technological and sociological changes, obsolete lay-out, and other factors, conditions existing in the District of Columbia with respect to substandard housing and blighted areas, including the use of buildings in alleys as dwellings for human habitation, are injurious to the public health, safety, morals, and welfare, and it is hereby declared to be the policy of the United States to protect and promote the welfare of the inhabitants of the seat of the Government by eliminating all such injurious conditions by employing all means necessary and appropriate for the purpose."1

${ }^{1}$ The Act does not define either "slums" or "blighted areas." Sec. $3(r)$, however, states: "Substandard housing conditions' means the conditions obtaining in connection with the existence of any dwelling, or dwellings, or housing accommodations for human beings, which because of lack of sanitary facilities, ventilation, or light, or because of dilapidation, overcrowding, faulty interior arrangement, or any combinations of these factors, is in the opinion of the Commissioners detrimental to the safety, health, morals, or welfare of the inhabitants of the District of Columbia." [Footnote, Berman v. Parker, 348 U.S. 26 (1954)].

Section 2 goes on to declare that acquisition of property is necessary to eliminate these housing conditions.

Congress further finds in $\$ 2$ that these ends cannot be attained "by the ordinary operations of private enterprise alone without public participation"; that "the sound replanning and redevelopment of an obsolescent or obsolescing portion" of the District "cannot be accomplished unless it be done in the light of comprehensive and coordinated planning of the whole of the territory of the District of Columbia and its environs"; and "that the acquisition and the assembly of real property and the leasing or sale thereof for redevelopment pursuant to a project area redevelopment plan ... is hereby declared to be a public use."

The main issue is clarified further here. Congress declares that it must use "all means necessary" and then goes on to declare "that acquisition of property is necessary" and further that this is a "public use." Because Congress declares something to be a "public use" does not necessarily mean that it is, in fact, a public use. Approximately seventy per cent of all new construction in federal urban renewal areas is privately owned-and this is clearly a private use as anyone may easily verify by attempting to use these homes or places of business as he would use a public park or a highway.

Section 4 creates the District of Columbia Redevelopment Land Agency (hereinafter called the Agency), composed of five members, which is granted power by $\S 5$ (a) to acquire and assemble, by eminent domain and otherwise, real property for "the redevelopment of blighted territory in the District of Columbia and the prevention, reduction, or elimination of blighting factors or causes of blight."

Section 6(a) of the Act directs the National Capital Planning Commission (hereinafter called the Planning Commission) to make and develop "a comprehensive or general plan" 
of the District, including "a land-use plan" which designates land for use for "housing, business, industry, recreation, education, public buildings, public reservations, and other general categories of public and private uses of the land." Section 6(b) authorizes the Planning Commission to adopt redevelopment plans for specific project areas. These plans are subject to the approval of the District Commissioners after a public hearing; and they prescribe the various public and private land uses for the respective areas, the "standards of population density and building intensity," and "the amount or character or class of any low-rent housing."

This section clearly shows that there is a contradiction in the Act itself. Earlier the process of federal urban renewal was "declared to be a public use." Here they clearly specify (twice) that there will be both "public and private uses of the land." Unless one attempts to maintain the intellectually indefensible position that a private use can be construed to be a public use (this is a contradiction in terms), then the only conclusion one can draw is that the wording of the Act itself is illogical and contradictory.

Once the Planning Commission adopts a plan and that plan is approved by the Commissioners, the Planning Commission certifies it to the Agency. $\S 6(\mathrm{~d})$. At that point, the Agency is authorized to acquire and assemble the real property in the area. Ibid.

After the real estate has been assembled, the Agency is authorized to transfer to public agencies the land to be devoted to such public purposes as streets, utilities, recreational facilities, and schools, $\S 7(\mathrm{a})$, and to lease or sell the remainder as an entirety or in parts to a redevelopment company, individual, or partnership. $\S 7(b),(f)$. The leases or sales must provide that the lessees or purchasers will carry out the redevelopment plan and that "no use shall be made of any land or real property included in the lease or sale nor any building or structure erected thereon" which does not conform to the plan. $\$ \$ 7$ (d), II. Preference is to be given to private enterprise over public agencies in executing the redevelopment plan. $\$ 7(\mathrm{~g})$.

This brief description of how the process of federal urban renewal will work implies that private use is involved. For example, it is stated that land can be sold or leased to an individual. By no distortion of the thinking process can this be construed to be a public use.

The first project undertaken under the Act relates to Project Area B in Southwest Washington, D.C. In I950 the Planning Commission prepared and published a comprehensive plan for the District. Surveys revealed that in Area B, 64.3\% of the dwellings were beyond repair, $18.4 \%$ needed major repairs, only $17.3 \%$ were satisfactory; $57.8 \%$ of the dwellings had outside toilets, $60.3 \%$ had no baths, $29.3 \%$ lacked electricity, $82.2 \%$ had no wash basins or laundry tubs, $83.8 \%$ lacked central heating. In the judgment of the District's Director of Health it was necessary to redevelop Area B in the interests of public health. The population of Area B amounted to 5,012 persons, of whom $97.5 \%$ were Negroes.

The plan for Area B specifies the boundaries and allocates the use of the land for various purposes. It makes detailed provisions for types of dwelling units and provides that at least one-third of them are to be low-rent housing with a maximum rental of $\$ 17$ per room per month. 
After a public hearing, the Commissioners approved the plan and the Planning Commission certified it to the Agency for execution. The Agency undertook the preliminary steps for redevelopment of the area when this suit was braught.

Appellants own property in Area B at 712 Fourth Streeet, S.W. It is not used as a dwelling or place of habitation. A department store is located on it. Appellants object to the appropriation of this property for the purposes of the project. They claim that their property may not be taken constitutionally for this project. It is commercial, not residential property; it is not slum housing; it will be put into the project under the management of a private, not a public, agency and redeveloped for private, not public, use. That is the argument; and the contention is that appellants' private property is being taken contrary to two mandates of the Fifth Amendment-( $r$ ) "No person shall . . . be deprived of ... property, without due process of law"; (2) "nor shall private property be taken for public use, without just compensation." To take for the purpose of ridding the area of slums is one thing; it is quite another, the argument goes, to take a man's property merely to develop a better balanced, more attractive community. The District Court, while agreeing in general with that argument, saved the Act by construing it to mean that the Agency could condemn property only for the reasonable necessities of slum clearance and prevention, its concept of "slum" being the existence of conditions "injurious to the public health, safety, morals and welfare." Ir7 F. Supp. 705, 724-725.

The power of Congress over the District of Columbia includes all the legislative powers which a state may exercise over its affairs. See District of Columbia v. John R. Thompson Co., 346 U.S. I00, 108.

This summarizes the situation that was presented to the Justices of the Supreme Court. Now Justice Douglas begins with the analysis and the conclusion derived therefrom, in which the rest of the Justices concurred.

We deal, in other words, with what traditionally has been known as the police power. An attempt to define its reach or trace its outer limits is fruitless, for each case must turn on its own facts. The definition is essentially the product of legislative determinations addressed to the purposes of government, purposes neither abstractly nor historically capable of complete definition. Subject to specific constitutional limitations, when the legislature has spoken, the public interest has been declared in terms well-nigh conclusive.

But the main point here is "subject to specific constitutional limitations"-and no matter what the purpose of the legislature, no matter how well-meaning, no matter how plausible the reasons, it is the responsibility of the Supreme Court to analyze logically the totality of the law-not only to see if the primary purposes of the law are unconstitutional, but also to see if anything incidental, but necessary, to the law is also unconstitutional.

For example, if Congress passed a law whose purpose was to eliminate slums, but which contained a proviso stating that the government could conscript labor for the actual physical work, the mere fact that the good of eliminating slums is desirable would not therefore justify the re-institution of slavery.

The fact that an action necessary to implement a law is incidental to the main purpose of the law does not mean that the "incidental" action is immune from scrutiny as to its constitutionality. 
In such cases the legislature, not the judiciary, is the main guardian of the public needs to be served by social legislation, whether it be Congress legislating concerning the District of Columbia (see Block v. Hirsh, 256 U.S. 135), or the States legislating concerning local affairs. See Olsen v. State of Nebraska, 313 U.S. 236; Lincoln Union v. Northwestern Co., 335 U.S. 525; California State Ass'n v. Maloney, 34x U.S. I05.

Of course, the legislature, and not the Supreme Court, is the governmental body that drafts and enacts laws. No one ever suggested the possibility that perhaps the Supreme Court was some sort of "Guardian." The role of the Supreme Court is to ascertain whether or not this legislation drafted by Congress is constitutional.

This principle admits of no exception merely because the power of eminent domain is involved. The role of the judiciary in determining whether that power is being exercised for a public purpose is an extremely narrow one. See Old Dominion Land Co. $v$. United States, 269 U.S. 55, 66; United States ex rel. TVA v. Welch, 327 U.S. 546, 552.

The Court states that its role "in determining whether that power is being exercised for a public purpose is an extremely narrow one." The critical word here is "purpose." But the issue is not whether eminent domain is being used for a public purpose, but rather whether the use of the land seized will be public or private.

The appellants claim-in the Court's own words-that their property, after it has been taken, "will be put into the project under the management of a private, not a public, agency and redeveloped for private, not public, use." The critical word here is "use."

According to the American College Dictionary the legal definition of "use" is "the enjoyment of property, as by the employment, occupation, or exercise of it." "Purpose," on the other hand, is "the object for which anything exists or is done, made, used, etc."

Use refers to the actual employment of material objects-to their occupation or to their exercise. Purpose refers to the object or goal for which any particular material object is used. Purpose and use do not mean the same thing.

The elementary point that should be decided by the Court is whether or not private property is being taken for public use or for private use. The question of whether or not it is for a public purpose is irrelevant here.

The word "public" pertains to the people as a whole-and thus the concept embraces every single individual within the community, state or nation that the context of its use implies. The word "private" means belonging to some particular person or persons.

To illustrate, the maintenance of an army would constitute a public purpose (in a national sense) because its function is to protect all the citizens of the nation. The maintenance of a police force by a community or city constitutes a public purpose (in a community sense) because it is used to protect all the citizens of the community 
or city. On the other hand, the maintenance of a police force for a privately owned housing development constitutes a private purpose, since it concerns only the particular individuals living in the housing development.

It appears that early in its analysis the Court has made a serious error. They have construed their role as one of determining whether the police power is being used for a public purpose. This is not the crucial issue. The crucial issue is whether or not private property can be taken for private use if the legislature decrees this taking to be for a public purpose. Whether or not the taking is for a public purpose is irrelevant to the question of whether or not the means employed to achieve this purpose result in an action that is clearly unconstitutional.

Public safety, public health, morality, peace and quiet, law and order-these are some of the more conspicuous examples of the traditional application of the police power to municipal affairs. Yet they merely illustrate the scope of the power and do not delimit it. See Noble State Bank v. Haskell, 219 U.S. 104, III.

It may be true that the traditional application of the police power to municipal affairs only illustrates the scope of its power and does not delimit it, but it does not follow from this that Supreme Court Justices have a carte blanche for deciding the desirable limits. The Court has no right to condone the extension of police power if this extension involves actions that are unconstitutional.

Miserable and disreputable housing conditions may do more than spread disease and crime and immorality. They may also suffocate the spirit by reducing the people who live there to the status of cattle. They may indeed make living an almost insufferable burden. They may also be an ugly sore, a blight on the community which robs it of charm, which makes it a place from which men turn. The misery of housing may despoil a community as an open sewer may ruin a river.

This highly emotional statement, while dealing with an important problem, does not pertain to the main point of constitutionality at issue here.

We do not sit to determine whether a particular housing project is or is not desirable. The concept of the public welfare is broad and inclusive. See Day-Brite Lighting, Inc. v. Missouri, 342 U.S. 421,424 . The values it represents are spiritual as well as physical, aesthetic as well as monetary. It is within the power of the legislature to determine that the community should be beautiful as well as healthy, spacious as well as clean, wellbalanced as well as carefully patrolled. In the present case, the Congress and its authorized agencies have made determinations that take into account a wide variety of values. It is not for us to reappraise them. If those who govern the District of Columbia decide that the Nation's Capital should be beautiful as well as sanitary, there is nothing in the Fifth Amendment that stands in the way.

The clear statement that it is within the power of the legislature to determine that the community should be beautiful, spacious and well-balanced has far reaching implications. In effect they are saying that Congress may dictate to the individual citizens of the United States what style of architecture they may build (because what is beautiful to one may not be to another), how much space should be between 
buildings, and what they must do to make the community "well-balanced." "Wellbalanced" puzzles me. Do they mean it should be racially balanced, and, if so, what ratio? Do they mean that it should be culturally balanced, and, if so, to what cultural activities are they referring?

Once the object is within the authority of Congress, the right to realize it through the exercise of eminent domain is clear. For the power of eminent domain is merely the means to the end. See Luxton v. North River Bridge Co., 153 U.S. 525, 529-530; United States v. Gettysburg Electric R. Co., I60 U.S. 668, 679. Once the object is within the authority of Congress, the means by which it will be attained is also for Congress to determine.

In simple terms, this says that the end justifies the means. This is an appalling philosophy to be upheld by any court, let alone the Supreme Court. Here the Court has clearly stated that if the Court agrees that the object of a law passed by Congress is within its authority, then it has no concern about the means used to acquire this object.

This is an illogical and immoral position. Clearly the means by which the legislature attempts to gain its ends must be moral and just-and when legislation is challenged, it is the responsibility of the Court to see to it that the means are constitutional, not to dismiss the issue.

What if Congress were to pass a law which had as its goal the elimination of poverty (clearly within the terms of "public welfare" as defined by the Court) and had as its means gas chambers to liquidate the poor who after all may be "a blight on the community which robs it of charm"? Would the Court declare that, "Once the object is within the authority of Congress, the means by which it will be attained is also for Congress to determine"? Of course not. The reasoning used by the Court here is illogical. The result of this error is to lead the Court into the untenable position where it implicitly adopts the principle that the means are irrelevant if the end is "good."

Here one of the means chosen is the use of private enterprise for redevelopment of the area. Appellants argue that this makes the project a taking from one businessman for the benefit of another businessman.

Taking from one businessman by force for the benefit of another businessman is not private enterprise. Private enterprise is based solely on voluntary trade-the use of physical force is prohibited. This is clearly government action with private individuals and firms engaged to carry out the task.

But the means of executing the project are for Congress and Congress alone to determine, once the public purpose has been established. See Luxton v. North River Bridge Co., supra; cf. Highland v. Russell Car Co., 279 U.S. 253. The public end may be as well or better served through an agency of private enterprise than through a department of government-or so the Congress might conclude. We cannot say that public ownership is the sole method of promoting the public purposes of community redevelopment 
projects. What we have said also disposes of any contention concerning the fact that certain property owners in the area may be permitted to repurchase their properties for redevelopment in harmony with the overall plan. That, too, is a legitimate means which Congress and its agencies may adopt, if they choose.

This clinches their position-the end justifies the means.

In the present case, Congress and its authorized agencies attack the problem of the blighted parts of the community on an area rather than on a structure-by-structure basis. That, too, is opposed by appellants. They maintain that since their building does not imperil health or safety nor contribute to the making of a slum or a blighted area, it cannot be swept into a redevelopment plan by the mere dictum of the Planning Commission or the Commissioners. The particular uses to be made of the land in the project were determined with regard to the needs of the particular community.

This last sentence is not quite accurate. It should read: "The particular uses to be made of the land in the project were determined with regard to the needs of particular people in the community." What happened to the "needs" of those living in the community whose property is to be seized? Why do the "needs" of some take precedence over the "needs" of others?

The experts concluded that if the community were to be healthy, if it were not to revert again to a blighted or slum area, as though possessed of a congenital disease, the area must be planned as a whole. It was not enough, they believed, to remove existing buildings that were insanitary or unsightly. It was important to redesign the whole area so as to eliminate the conditions that cause slums-the overcrowding of dwellings, the lack of parks, the lack of adequate streets and alleys, the absence of recreational areas, the lack of light and air, the presence of outmoded street patterns. It was believed that the piecemeal approach, the removal of individual structures that were offensive, would be only a palliative. The entire area needed redesigning so that a balanced, integrated plan could be developed for the region, including not only new homes but also schools, churches, parks, streets, and shopping centers. In this way it was hoped that the cycle of decay of the area could be controlled and the birth of future slums prevented. CF. Gohld Realty Co. v. Hartford, I4I Conn. 135, I4I-I44, I04 A.2d 365, 368-370; Hunter v. Redevelopment Authority, 195 Va. 326, 338-339, 78 S.E.2d 893, 900-901. Such diversification in future use is plainly relevant to the maintenance of the desired housing standards and therefore within congressional power.

The implication of this whole section is that if the "experts" say it is so, it is so, and therefore is desirable, lawful and just. I find it quite incredible that Justices of the Supreme Court could ascribe such knowledge and wisdom to city planning experts. The profession of city planning is in its intellectual infancy-and there are few generally accepted standards or criteria by which these people operate.

The District Court below suggested that, if such a broad scope were intended for the statute, the standards contained in the Act would not be sufficiently definite to sustain the delegation of authority. II F. Supp. 705, 72I. We do not agree. We think the standards prescribed were adequate for executing the plan to eliminate not only slums as narrowly defined by the District Court but also the blighted areas that tend to produce slums. 
At this point I can only refer to the footnote that the Court itself appended to its opinion. In the footnote the Court states, "The Act does not define either 'slums' or "blighted area," and now, a few pages later in the same opinion, they say, "We think the standards prescribed were adequate. ..."The logic here is impeccably false. Standards that do not exist cannot be adequate.

Property may of course be taken for this redevelopment which, standing by itself, is innocuous and unoffending. But we have said enough to indicate that it is the need of the area as a whole which Congress and its agencies are evaluating. If owner after owner were permitted to resist these redevelopment programs on the ground that his particular property was not being used against the public interest, integrated plans for redevelopment would suffer greatly. The argument pressed on us is, indeed, a plea to substitute the landowner's standard of the public need for the standard prescribed by Congress. But as we have already stated, community redevelopment programs need not, by force of the Constitution, be on a piecemeal basis-lot by lot, building by building.

It is not for the courts to oversee the choice of the boundary line nor to sit in review on the size of a particular project area. Once the question of the public purpose has been decided, the amount and character of land to be taken for the project and the need for a particular tract to complete the integrated plan rests in the discretion of the legislative branch. See Shoemaker v. United States, $x_{47}$ U.S. 282; United States ex rel. TVAv. Welch, supra, 327 U.S. at 554; United States v. Carmack, 329 U.S. 230, 247.

For the third time-the end justifies the means.

The District Court indicated grave doubts concerning the Agency's right to take full title to the land as distinguished from the objectionable buildings located on it. II7 F. Supp. 705, 715-719. We do not share those doubts. If the Agency considers it necessary in carrying out the redevelopment project to take full title to the real property involved, it may do so. It is not for the courts to determine whether it is necessary for successful consummation of the project that unsafe, unsightly, or insanitary building alone be taken or whether title to the land be included, any more than it is the function of the courts to sort and choose among the various parcels selected for condemnation.

The Supreme Court Justices do not seem to share anyone's doubts with regard to any areas concerning this case. Now they say that "if the Agency (not the legislature) considers it necessary ... to take full title to the real property, it may do so." Does this also imply that the Court would support anything the "Agency" wished to do as long as the "Agency" considered it necessary?

The rights of these property owners are satisfied when they receive that just compensation which the Fifth Amendment exacts as the price of the taking.

There are many property owners and others that do not agree that their rights are satisfied simply by receiving what someone else thinks their seized property is worth.

The judgment of the District Court, as modified by this opinion, is affirmed. 


\section{Conclusion}

In essence the Supreme Court was presented with the established fact that a law had been passed by Congress which involved, as part of the means of implementation, the taking of private property by eminent domain for private use. This is proven by the fact that approximately seventy per cent of the new construction in urban renewal areas is privately owned, and also by the intent and wording of the act itself.

The Constitution is unequivocal on this question. A specific reference clearly states, "nor shall private property be taken for public use, without just compensation." And "for public use" is not the same as "for public purpose."

Faced with this problem the Justices appear to have found themselves in something of a dilemma. They had three alternatives: (I) If they decided that the Constitution meant what it said, it would mean the end of the FURP. If they found this alternative unpalatable, they had two other possibilities. (2) They could declare that private property could be taken by eminent domain for private use, or (3) they could somehow attempt to evade the issue and simply declare that the FURP was constitutional because it was "within the power of the legislature to determine that the community should be beautiful as well as healthy, spacious as well as clean, well-balanced as well as beautiful" and then go on to say that "the power of eminent domain is merely the means to the end."

By not taking the first alternative, which, in my judgment, is the only logical conclusion, they were left with two untenable choices. To accept the second alternative would put them clearly on record in favor of allowing private property to be seized by eminent domain for private use. The enormous implications of a clear, unqualified acceptance of this principle probably deterred them from this course. Thus, they were left with only one alternative: to somehow allow eminent domain to be used as a tool in the FURP, and to evade any clear endorsement of the principle involved.

This is the course they followed by concurring in the opinion drafted by Justice Douglas. If we take this opinion literally, the Court has upheld the general principle that the end can justify the means, and that once the legislature has determined the end, the means are incidental to it, thus clearly implying that the crucial issue of whether or not a law is constitutional is irrelevant when the law deals only with the means employed to gain some particular end.

But it is obvious that the means of any legislation must clearly lie within the specific limitations of the Constitution. To declare otherwise is to revert in history to the rule of men, and to abandon the rule of law and the concept of human rights. An evasive decision of this type simply allows government seizure of private property by eminent domain for private use without openly endorsing it.

On the other hand, it might be that the Court simply did not address itself to the main issue raised in Berman v. Parker: Is it constitutional to seize private 
property by eminent domain for private use? The Justices are human, and thus fallible, and it is certainly reasonable to expect some errors in the decisions they make, particularly when one considers the tremendous time pressures under which they operate.

If this is the case, then they should rule on this crucial issue at some time in the future, and steer clear of expounding on what they feel is in the best interests of the community. When, and if, they do face this issue squarely, they will have to choose between the following alternatives:

r. Rule that private property cannot be taken by eminent domain for private use, and thus eliminate the FURP.

2. Rule that private property can be taken by eminent domain for private use, and thus cause the FURP to continue. Of course, the adoption of this principle has far-reaching implications. It means that no man's property would be absolutely safe from seizure by a government official, if that government official maintained that the seizure was for a "public purpose" and could show this to the satisfaction of the Court.

In my judgment, the first alternative is the only logical and moral course to follow. 